\title{
EVALUASI PROSEDUR PENGELUARAN KAS DENGAN MENGGUNAKAN UANG PERSEDIAAN PADA DINAS PENDAPATAN DAERAH KOTA MANADO
}

\author{
Windy Firginia Dendeng ${ }^{1}$, Inggriani Elim² ${ }^{2}$ Heince Rudy Nicky Wokas ${ }^{3}$ \\ 1,2,3 Jurusan Akuntansi, Fakultas Ekonomi dan Bisnis, Universitas Sam Ratulangi, Jl. Kampus Bahu, Manado, \\ 95115, Indonesia
}

E-mail: windyfirginia07@gmail.com

\begin{abstract}
The implementation of a government system that is synergic and fair with the principle of decentralization requires the existence of a financial management that is accountable and transparent. Evaluation of cash disbursement procedures for money supply is a form of financial management that is accountable and transparent. Inventory money is the initial fund given to the regional government SKPD at the beginning of the fiscal year as an advance for the implementation of SKPD operational activities. The purpose of this study was to evaluate the implementation of the procedure for the issuance of cash in cash inventories in the regional income department of the city of Manado. The analytical method used in this research is descriptive analysis method. The results showed that the implementation of the procedure for issuing cash in the form of cash in the regional income department of the city of Manado was not yet effective and was not in accordance with SE.900/316/BAKD because some supporting documents required by law were not attached and for the use of money the supplies still needed control and supervision in accordance with regulation number 60 of 2008 concerning the government's internal control system.
\end{abstract}

Keywords : procedure; cash expenditures; money supply

\section{PENDAHULUAN}

Sebagai salah satu instansi pemerintahan yang memiliki kewajiban untuk menyelenggarakan penyusunan, pelaksanaan dan pelaporan Anggaran Pendapatan dan Belanja Daerah (APBD), Pemerintah Daerah Provinsi Sulawesi Utara sudah melaksanakan proses penganggaran sesuai dengan Peraturan Daerah (Perda) yang berlaku dan kemudian menyusun dan melaksanakan kegiatan APBD yang mengacu pada Peraturan Menteri Dalam Negeri (Permendagri) Nomor 57 Tahun 2007 sebagai pedoman pelaksanaan, penatausahaan hingga laporan keuangan dimana mencakup kebijakan akuntansi yang merupakan dasar yang harus dipatuhi dalam menyusun laporan keuangan.

Belanja daerah atau dikenal dengan pengeluaran pemerintah daerah pada APBD yaitu merupakan salah satu faktor pendorong pertumbuhan ekonomi daerah. APBD adalah Anggaran Pendapatan dan Belanja suatu daerah untuk satu tahun berjalan (1 periode) yang ditetapkan dengan Peraturan Daerah (Perda). APBD disusun oleh Badan Eksekutif (Pemerintah Provinsi) dan Legislatif (DPRD). Salah satu tujuan dibuat anggaran adalah untuk membiayai seluruh belanja rutin pegawai dan kegiatan publik dalam rangka meningkatkan kesejahteraan rakyat.

Bersamaan dengan peranan pemerintah daerah yang mengelola keuangan daerahnya sendiri sebagai upaya untuk mengoptimalkan potensi pendapatan pada tiap-tiap daerah guna meningkatkan perkembangan daerah tersebut, pendapatan pada tiap-tiap daerah tersebut harus maksimal. Seperti ditegaskan dalam Undang-undang Republik Indonesia Nomor 32 Tahun 2004 tentang pemerintahan daerah bahwa otonomi daerah menggunakan prinsip otonomi seluas-luasnya dalam arti daerah diberikan kewenangan mengurus dan mengatur semua urusan pemerintahan di luar urusan pemerintah pusat yang ditetapkan dalam Undang- 
Undang tersebut. Oleh karena itu, penyelenggaraan otonomi daerah harus selalu berorientasi pada peningkatan kesejahteraan masyarakat dengan selalu memperhatikan kepentingan dan aspirasi yang tumbuh dalam masyarakat. Untuk itu, otonomi daerah diharapkan dapat menciptakan efisiensi dan efektivitas pengelolaan sumber daya daerah, meningkatkan kualitas pelayanan umum dan kesejahteraan masyarakat, dan membudayakan dan menciptakan ruang bagi masyarakat untuk ikut berpartisipasi dalam proses pembangunan.

Dinas Pendapatan Daerah Kota Manado sebagai salah satu Satuan Kerja Perangkat Daerah (SKPD) di lingkup Pemerintah Provinsi Sulawesi Utara dalam kegiatannya menggunakan dana APBN dan APBD. Dana APBD yang tertuang dalam DPA diupayakan semaksimal mungkin untuk pencapaian realisasinya disesuaikan dengan anggaran kas dan target yang ditentukan. Dalam proses penyerapan dana APBD, sistem dan prosedur akuntansi pengeluaran kas yang digunakan terdiri dari 4 (empat) sub sistem yaitu sub sistem akuntansi pengeluaran kas pembebanan uang persediaan (UP), sub sistem akuntansi pengeluaran kas pembebanan ganti uang persediaan (GU), sub sistem akuntansi pengeluaran kas pembebanan tambahan uang persediaan (TU), dan sub sistem akuntansi pengeluaran kas pembebanan langsung (LS). Pelaksanaan realisasi anggaran dapat dijadikan acuan untuk mengetahui sejauh mana anggaran tersebut dipergunakan. Surat Perintah Pencairan Dana (SP2D) adalah surat yang dipergunakan untuk mencairkan dana lewat bank persepsi yang ditunjuk setelah Standar Pelayanan Minimal diterima kuasa Bendahara Umum Daerah. Dapat diterbitkan jika pengeluaran yang diminta tidak melebihi pagu anggaran yang tersedia dan didukung dengan kelengkapan dokumen sesuai peraturan perundangan.

\section{TINJAUAN PUSTAKA}

Akuntansi. Menurut Sumarsan (2013:1), akuntansi merupakan sebuah seni untuk mengumpulkan, mengidentifikasikan, mengklasifikasikan, mencatat transaksi dan juga kejadian yang berkaitan dengan keuangan. Sehingga mampu menghasilkan informasi yang berguna dan kemudian menyajikannya dalam bentuk laporan keuangan yang bisa dipakai oleh pihak-pihak yang berkepentingan. Horngren et al. (1999:6) menjelaskan bahwa "Accounting is the Information System that measures business activities, processes that information into reports and communicates the result to decision maker". Artinya, akuntansi adalah sistem informasi yang mengukur aktivitas bisnis, memproses informasi, menjadi laporan keuangan dan mengkomunikasikan hasilnya kepada para pembuat keputusan.

Mardiasmo (2009:2) mengartikan bahwa akuntansi sektor publik adalah alat informasi, baik bagi pemerintah sebagai manajemen maupun alat informasi bagi publik. Akuntansi sektor publik berkaitan dengan tiga hal pokok, yaitu penyedia informasi, pengendalian manajemen, dan akuntabilitas. Renyowijoyo (2008:25) menyatakan bahwa akuntansi sektor publik merupakan sistem akuntansi yang dipakai oleh lembaga-lembaga publik sebagai salah satu alat pertanggung jawaban kepada publik.

Dapat disimpulkan bahwa akuntansi adalah suatu kegiatan jasa, suatu seni atau ilmu, juga merupakan suatu sistem informasi yang meliputi pencatatan, pengidentifikasian/penggolongan, peringkasan/ pengikhtisaran, dan pelaporan data keuangan suatu organisasi atau perusahaan dari transaksi atau kejadian ekonomi dengan cara yang informatif dan berguna bagi para pemakai dalam pengambilan keputusan yang tepat.

Sistem Informasi Akuntansi Pengeluaran Kas. Mulyadi (2017:425) menjelaskan bahwa pengeluaran kas dengan cek memiliki kebaikan ditinjau dari pengendalian interen berikut ini:

1. Dengan digunakannya cek atas nama, pengeluaran cek akan dapat diterima oleh pihak yang namanya sesuai dengan yang ditulis pada formulir cek. Dengan demikian pengeluaran kas dengan cek menjamin diterimanya cek tersebut oleh pihak yang dimaksud oleh pihak pembayar. 
2. Dilibatkannya pihak luar dalam hal ini Bank, dalam pencatatan transaksi pengeluaran kas perusahaan. Dengan diadakannya cek dalam setiap pengeluaran kas perusahaan transaksi pengeluaran kas direkam juga oleh bank yang secara periodik mengirimkan rekening koran bank (bank statement) kepada perusahaan nasabahnya. Rekening koran inilah yang dapat digunakan perusahaan untuk mengecek ketelitian catatan transaksi kas perusahaan yang direkam dalam jurnal penerimaan dan pengeluaran kas.

3. Jika sistem perbankan mengembalikan cancelled check kepada check issuer, pengeluaran kas dengan cek memberikan manfaat bagi perusahaan yang mengeluarkan cek dengan dapat digunakannya cancelled check sebagai tanda terima kas dari pihak yang menerima pembayaran. Dengan digunakannya cek dalam pengeluaran kas, check issuer akan secara otomatis menerima tanda penerimaan kas dari pihak yang menerima pembayaran. Cancelled check sebagai tanda terima pembayaran lebih andal karena didalam endorsement terkait pihak bank yang merupakan pihak yang independen bagi pembayar maupun penerima pembayaran.

Catatan yang digunakan. Mulyadi (2017:445) menjelaskan bahwa dalam sistem informasi akuntansi pengeluaran kas adalah:

a. Jurnal pengeluaran kas (Cash Disbursement Journal). Dalam pencatatan utang account payable system, untuk mencatat transaksi pembelian yang digunakan jurnal pembelian dan untuk mencatat pengeluaran kas digunakan jurnal pengeluaran kas. Dokumen standar yang dipakai sebagai dasar pencatatan dalam jurnal pengeluaran kas adalah faktur dari pemasok yang telah dicap "lunas" oleh fungsi kas.

b. Register Cek (Check Register). Dalam pencatatan utang dengan voucher payable system, transaksi untuk mencatat transaksi pembelian digunakan dua jurnal, register bukti kas keluar dan register cek. Register bukti kas keluar digunakan untuk mencatat utang yang timbul, sedangkan register cek digunakan untuk mencatat pengeluaran kas dengan cek. Register cek digunakan untuk mencatat cek-cek perusahaan yang dikeluarkan untuk membayar para kreditur perusahaan atau pihak lain.

Prosedur Pengeluaran Kas. Soemarso (1992:325) menjelaskan bahwa untuk dapat menghasilkan sistem pengawasan yang baik, prosedur pengeluaran uang harus memperhatikan hal sebagai berikut: semua pengeluaran dilakukan dengan cek, pengeluaranpengeluaran dalam jumlah kecil dilakukan melalui dana kas kecil. Semua pengeluaran kas harus memperoleh persetujuan dari yang berwenang terlebih dahulu. Terdapat pemisahan tugas antara yang berhak menyetujui pengeluaran kas, yang menyimpan uang kas dan melakukan pengeluaran kas serta yang mencatat pengeluaran kas.

Baridwan (1997:87) menjelaskan bahwa ada beberapa prosedur-prosedur pengawasan terhadap pengeluaran kas yang penting adalah sebagai berikut: semua pengeluaran uang menggunakan cek, kecuali untuk pengeluaran-pengeluaran kecil dibayar dari kas kecil, dibentuk kas kecil yang diawasi dengan ketat, pelulusan cek hanya dilakukan apabila didukung bukti-bukti yang lengkap atau dengan kata lain digunakan sistem voucher, dipisahkan antara orang yang mengumpulkan bukti-bukti pengeluaran kas, yang menulis cek, yang menandatangani cek, dan yang mencatat penerimaan kas, diadakan pemeriksaan interen dalam waktu yang tidak tentu dan diharuskan membuat laporan kas harian.

Penelitian terdahulu. Languju et al. (2015) menujukkan bahwa sistem dan prosedur telah dilaksanakanan sudah sesuai dengan aturan. Noviana (2009) menunjukkan bahwa Dinas Tata Kota Tata Bangunan Kota Medan telah menerapkan sistem pencatatan dan pelaporan keuangan sesuai dengan Peraturan Pemerintah Nomor 24 Tahun 2005 dan Peraturan Menteri Dalam Negeri (Permendagri) Nomor 13 Tahun 2006 yang dimulai untuk tahun anggaran 2007. Pasuhuk et al. (2018) menemukan bahwa sistem dan prosedur uang persediaan pada Dinas Lingkungan Hidup Daerah Provinsi Sulawesi Utara khususnya pada prosedur penerbitan surat penyediaan, belum sesuai dengan Peraturan Menteri Dalam Negeri 
(Permendagri) Nomor 13 Tahun 2006 tentang pengelolaan keuangan daerah hal ini juga disebabkan karena penerbitan Surat Penyediaan Dana seharusnya dilakukan Pelaksana Pengelolaan Keuangan Desa (PPKD) dalam rangka manajemen kas dan disiapkan oleh Bendahara Umum Daerah untuk di tandatangani oleh PPKD. Ointu dan Budiarso (2016) menunjukkan bahwa Dinas Pendapatan Pengelolaan Keuangan dan Kekayaan Aset Daerah (DPPKAD) berjalan belum efektif karena belum sesuai dengan Surat Edaran Dirjen Bina Adiministrasi Keuangan Daerah SE.900/316/BAKD. Kapoh et al. (2015) menemukan bahwa sistem dan prosedur pengeluaran kas uang persediaan pada Dinas Pariwisata dan Kebuadayaan Kota Manado telah dilaksanakan sudah sesuai dengan aturan.

\section{METODE PENELITIAN}

Jenis penelitian yang digunakan adalah jenis penelitian deskriptif yang diartikan sebagai suatu bentuk penelitian ditujukan untuk mendeskripsikan fenomena-fenomena yang ada, baik fenomena alamiah maupun fenomena buatan manusia. Fenomena itu biasa berupa bentuk, aktivitas, karakteristik, perubahan, hubungan, kesamaan dan perbedaan antara fenomena yang satu dengan fenomena yang lainnya. Penelitian ini dilakukan terhadap objek tertentu disertai dengan pengumpulan data selama periode tertentu, kemudian data tersebut dievaluasi sehingga dapat memberikan kesimpulan yang cukup jelas atas objek yang diteliti. Metode pengumpulan data yang digunakan dalam penelitian ini adalah observasi, inspeksi, wawancara, dan studi kepustakaan. Metode analisis data yang digunakan dalam penelitian ini adalah metode deskriptif, yaitu membahas masalah dengan cara mengumpulkan, menguraikan, menghitung, dan membandingkan suatu keadaan serta menjelaskan suatu keadaan sehingga dapat ditarik kesimpulan yang meliputi sistem dan prosedur pengeluaran kas dengan menggunakan uang persediaan.

\section{HASIL PENELITIAN DAN PEMBAHASAN}

\subsection{Hasil penelitian}

Dinas Pendapatan Daerah Kota Manado sebagai Dinas Daerah, dipimpin oleh seorang Kepala Dinas yang berada di bawah dan bertanggung jawab kepada Walikota melalui Sekretaris Daerah Kota Manado. Sistem akuntansi pengeluaran kas yang ada di Satuan Kerja Perangkat Daerah (SKPD) Dinas Pendapatan Daerah Kota Manado terdiri atas 4 sub sistem yaitu : (a) Sub Sistem Akuntansi Pengeluaran Kas-Pembebanan Uang Persediaan (UP); (b) Sub Sistem Akuntansi Pengeluaran Kas-Pembebanan Ganti Uang Persediaan (GU); (c) Sub Sistem Akuntansi Pengeluaran Kas-Pembebanan Tambahan Uang Persediaan (UP); dan (d) Sub Sistem Akuntansi Pengeluaran Kas-Pembebanan Langsung (LS).

Surat Penyediaan Dana (SPD) dibuat oleh Bendahara Umum Daerah (BUD) dalam rangka manajemen kas daerah dan digunakan untuk menyediakan dana bagi tiap-tiap SKPD dalam waktu tertentu. Informasi dalam SPD menunjukkan secara jelas alokasi tiap kegiatan yang diterbitkan terdiri atas 3 (tiga) lembar, terdiri atas: (1) Lembar 1 diterima oleh Bendahara Pengeluaran Pembantu-SKPD; (2) Lembar 2 diterima oleh Bendahara Pengeluaran-SKPD; (3) Lembar 3 sebagai arsip Pejabat Pengelola Keuangan (PPKD) selaku Bendahara Umum Daerah. Pihak Terkait :

1. Kuasa Bendahara Umum Daerah (BUD) dalam kegiatan ini mempunyai tugas: menganalisa Dokumen Pelaksanaan Anggaran Satuan Kerja Perangkat Daerah (DPASKPD) yang ada dalam database, menganalisa anggaran kas pemerintah khususnya data per SKPD, menyiapkan draft Surat Penyediaan Dana dan mendistribusikan kepada para pengguna anggaran.

2. Pejabat Pengelola Keuangan Daerah (PPKD) dalam kegiatan ini mempunyai tugas: meneliti draft Surat Penyediaan Dana yang diajukan kuasa Bendahara Umum Daerah dan melakukan otorisasi Surat Penyediaan Dana. Prosedur pengajuan Surat Penyediaan Dana 
Ganti Uang (SPD-GU) secara rinci adalah: setelah penetapan anggaran kas, PPKD dalam rangka manajemen kas menerbitkan Surat Penyediaan Dana, berdasarkan surat permintaan dari SKPD, Surat Penyediaan Dana disiapkan oleh kuasa Bendahara Umum Daerah untuk ditandatangani oleh PPKD, pengeluaran kas atas beban APBD dilakukan berdasarkan Surat Penyediaan Dana atau dokumen lain yang dipersamakan, dengan itu bendahara pengeluaran mengajukan Surat Perintah Pembayaran (SPP) kepada Pengguna Anggaran/Kuasa Pengguna Anggaran melalui Pejabat Penatausahaan Keuangan SKPD.

Standar Pelayanan Minimal (SPM) adalah tahapan penting dalam penatausahaan pengeluaran yang merupakan tahap lanjutan dari proses pengajuan SPP. Sebagai tahap lanjutan, SPM juga dibedakan menjadi 4 (empat) sesuai dengan jenis SPP nya, yaitu SPMUP, SPM-GU, SPM-TU dan SPM-LS. SPM dapat diterbitkan jika: Pengeluaran yang diminta tidak melebihi pagu anggaran yang tersedia dan didukung dengan kelengkapan dokumen sesuai dengan peraturan perundang-undangan. Waktu pelaksanaan penerbitan SPM paling lambat 2 (dua) hari sejak SPP diterima, apabila ditolak, dikembalikan paling lambat 1 (satu) hari sejak diterima SPP. SPM yang diajukan dibuat rangkap 3 (tiga), antara lain :

a. Lembar 1 dan 2 untuk Kepala SKPD/Pengguna Anggaran yang diteruskan ke PPKD dan

PPK SKPD, setelah ditandatangani oleh Kepala SKPD/Pengguna Anggaran

b. Lembar 3 diarsip oleh Bendahara Pengeluaran Pembantu.

Surat Perintah Pencairan Dana (SP2D) adalah spesifik, artinya satu SP2D hanya dibuat untuk satu SPM saja. Waktu pelaksanaan penerbitan SP2D paling lambat 2 hari sejak SPM diterima, apabila ditolak, dikembalikan paling lambat 1 hari sejak diterima SPM. Penerbitan SP2D terdiri atas 5 lembar yang terdiri atas: lembar 1 dikirim ke bank, lembar 2 diarsip oleh Bendahara Pengeluaran Pembantu, lembar 3 diarsip oleh fungsi akuntansi SKPKD, lembar 4 diarsip oleh fungsi akuntansi PPK-SKPD dan lembar 5 diarsip oleh PPKD.

Surat Pertanggungjawaban (SPJ) merupakan dokumen yang menjelaskan penggunaan dana-dana yang dikelola oleh bendahara pengeluaran. Bendahara pengeluaran secara administratif wajib mempertanggungjawabkan penggunaan uang persediaan/ganti uang persediaan/tambah uang persediaan (UP/GU/TU) kepada kepala SKPD melalui PPKSKPD paling lambat tanggal 10 bulan berikutnya. Dokumen yang digunakan oleh PPKSKPD dalam menatausahakan pertanggungjawaban pengeluaran mencakup:

a. Register penerimaan laporan pertanggungjawaban pengeluaran (SPJ)

b. Register pengesahan laporan pertanggungjawaban pengeluaran (SPJ)

c. Surat penolakan laporan pertanggungjawaban pengeluaran (SPJ)

d. Register penolakan laporan pertanggungjawaban pengeluaran (SPJ)

e. Register penutupan kas.

\subsection{Pembahasan}

Evaluasi atas sistem akuntansi dimaksudkan guna memperoleh pemahaman proses setiap dokumen, catatan akuntansi, pihak yang terkait dan prosedur yang digunakan dalam proses pengeluaran kas atas Uang Persediaan (UP) dalam bentuk Ganti Uang (GU), pada Dinas Pendapatan Daerah Kota Manado. Mekanisme penggunaan Uang Persediaan (UP) hanya dapat digunakan untuk pengeluaran rutin SKPD dan pengeluaran - pengeluaran pada program dan kegiatan pada pos belanja barang dan jasa yang bersifat kecil dengan nominal< Rp. 10 juta. Uang Persediaan (UP) diisi kembali dengan mekanisme Ganti Uang (GU).

Evaluasi fungsi yang terkait. Berdasarkan pelaksanaannya setiap fungsi telah berjalan dengan baik dan dilaksanakan oleh orang yang berbeda. Verifikasi dokumen dan persyaratan menjadi hal yang sangat penting sehingga dilakukan disetiap pihak terkait. Berdasarkan hasil penelitian, Dinas Pendapatan Daerah Kota Manado telah melibatkan beberapa bagian sehingga dapat mencegah terjadinya penyimpangan. Proses yang ada telah efektif dan sesuai dengan peraturan perundang-undangan yang berlaku. 
Evaluasi dokumen yang digunakan. Dokumen yang digunakan dalam sistem pengeluaran kas atas Uang Persediaan (UP) dalam bentuk Ganti Uang (GU) pada Dinas Pendapatan Daerah Kota Manado, sudah cukup baik dan digunakan sebagaimana mestinya. Surat Penyediaan Dana (SPD) berdasarkan permintaan dari SKPD dikeluarkan oleh PPKD selaku BUD. Dokumen yang digunakan sudah cukup baik dan sesuai dengan prosedur yang ada. Dokumen yang digunakan lebih dari 1 lembar sehingga fungsi kontrol dapat dilakukan oleh fungsi yang berhubungan. Proses yang ada telah efektif dan sesuai dengan peraturan dan perundang-undangan yang berlaku.

Evaluasi catatan akutansi yang digunakan. Pencatatan setiap transaksi pengeluaran kas atas Uang Persediaan (UP) dalam bentuk Ganti Uang (GU) pada Dinas Pendapatan Daerah Kota Manado menggunakan catatan akuntansi secara komputerisasi melalui aplikasi Sistem Informasi Manajemen Daerah (SIMDA) Keuangan versi 2.1 oleh BPKP, dimana semua jurnal dan neraca bisa langsung dicetak. Berdasarkan hasil penelitian dapat dikatakan bahwa catatan akuntansi telah memadai dan dapat mencegah terjadi penyimpangan, proses yang ada telah efektif dan sesuai dengan peraturan dan perundang-undangan yang berlaku.

Evaluasi prosedur pengeluaran kas atas Uang Persediaan (UP) dalam bentuk Ganti Uang (GU). Prosedur pengeluaran kas atas Uang Persediaan (UP) dalam bentuk Ganti Uang (GU) Dinas Pendapatan Daerah Kota Manado yang ada telah membentuk sistem dan sesuai dengan flowchart yang baku, namun penerapannya sering terjadi keterlambatan pada masing-masing unit kerja. Hal ini disebabkan tidak meratanya sumber daya manusia dan beberapa perangkat pendukung teknis yang tidak bekerja dengan optimal. Setiap unit kerja memiliki Standar Operasional Prosedur (SOP) sehingga apabila terdapat keterlambatan maka itu disebabkan oleh karena adanya staf yang menunda-nunda pekerjaan ataupun karena adanya masalah jaringan. Hal itulah yang mengakibatkan prosedur pengeluaran kas atas UP dalam bentuk GU pada Dinas Pendapatan Daerah Kota Manado berjalan lambat. Untuk itu sebaiknya setiap pihak terkait menjalankan tugas sesuai dengan tanggungjawabnya agar tidak terjadi keterlambatan dan kesalahpahaman dalam pekerjaan.

\section{KESIMPULAN DAN SARAN}

\subsection{Kesimpulan}

Berdasarkan pembahasan, maka kesimpulan atas penelitian ini adalah:

1. Pelaksanaan prosedur akuntansi pengeluaran kas atas uang persediaan di Dinas Pendapatan Daerah Kota Manado telah dilakukan sesuai dengan aturan yang ada mencakup fungsi yang terkait, dokumen yang digunakan, catatan akuntansi yang digunakan dan jaringan prosedur sistem akuntansi pengeluaran kas.

2. Prosedur pengeluaran kas atas uang persediaan pada Dinas Pendapatan Daerah Kota Manado, sudah memiliki standar yang baku, namun belum berjalan efektif karena belum sesuai dengan Surat Edaran Direktorat Jenderal Bina Administrasi Keuangan Daerah SE.900/316/BAKD yang merupakan penjabaran dari Peraturan Menteri Dalam Negeri (Permendagri) Nomor 13 Tahun 2006 tentang pengelolaan keuangan daerah, hal ini disebabkan oleh tidak terpenuhinya beberapa dokumen yang dipersyaratkan. Sedangkan untuk pengendalian internal tidak dijalankan dengan baik untuk penggunaan uang persediaan dan pertanggungjawabanya sehingga beresiko terjadinya kecurangan atau penyelewengan.

\subsection{Saran}

1. Dalam pelaksanaan sistem penatausahaan pengelolaan keuangan daerah dibutuhkan tenaga sumber daya manusia atau pegawai untuk menjalankan perangkat pendukung yang digunakan dalam sistem akuntansi pengeluaran kas tersebut. Sehubungan dengan aplikasi sistem akuntansi pemerintah daerah yang merupakan program tersendiri, maka 
dibutuhkan lebih banyak pegawai yang mengerti dengan baik dan dapat menjalankan secara benar program aplikasi tersebut.

2. Dalam pelaksanaan sistem akuntansi pengeluaran kas membutuhkan perangkat pendukung teknis yang mampu bekerja dan digunakan optimal sehingga penyusunan laporan dapat dilakukan dengan baik. Perangkat pendukung teknis merupakan unit computer yang mampu melaksanakan perhitungan-perhitungan dengan cepat dan akurat.

3. Diharapkan adanya pelatihan dalam bidang akuntansi agar dalam proses kinerja dapat berjalan sesuai yang diharapkan.

\section{DAFTAR PUSTAKA}

Baridwan, Z. (1997). Intermediate accounting. Yogyakarta: Bhakti Profesindo (BPFE) Horngren, C. T., Harrison, W. T., \& Bamber, L. S. (1999). Accounting, $4^{\text {th }}$, Edition. New Jersey: Prentice Hall

Kapoh, I., Karamoy, H., \& Sabijono, H. (2015). Evaluasi pelaksanaan sistem dan prosedur pengeluaran kas uang persediaan pada Dinas Pariwisata dan Kebudayaan Kota Manado. Jurnal EMBA: Jurnal Riset Ekonomi, Manajemen, Bisnis dan Akuntansi. 3(1), 1053-1062. https://ejournal.unsrat.ac.id/index.php/emba/article/view/7810

Languju, G. V., Tinangon, J. J., \& Pusung, R. J. (2015). Evaluasi pelaksanaan sistem dan prosedur pengeluaran kas pada dinas perindustrian dan perdagangan Provinsi Sulawesi Utara. Jurnal EMBA: Jurnal Riset Ekonomi, Manajemen, Bisnis dan Akuntansi. $3(1)$,

1044-1052. https://ejournal.unsrat.ac.id/index.php/emba/article/view/7809

Mardiasmo. (2009). Akuntansi sektor publik. Yogyakarta: Penerbit Andi.

Mulyadi. (2017). Sistem akuntansi. Jakarta: Salemba Empat

Noviana, E. (2009). Analisis pencatatan dan pelaporan keuangan pada satuan kerja perangkat daerah di pemerintah Kota Medan studi kasus pada Dinas Tata Kota Tata Bangunan. Skripsi. Fakultas Ekonomi USU. http://repository.usu.ac.id/handle/123456789/9576

Ointu, M. R., \& Budiarso, N. (2016). Evaluasi pelaksanaan sistem dan prosedur pengeluaran kas uang persediaan pada DPPKAD Kabupaten Bolmong. Jurnal EMBA: Jurnal Riset Ekonomi, Manajemen, Bisnis dan Akuntansi. 4(3). 156-164. https://ejournal.unsrat.ac.id/index.php/emba/article/view/13662

Peraturan Menteri Dalam Negeri Republik Indonesia No. 13 Tahun 2006 Tentang Pengelolaan Keuangan Daerah.

Peraturan Pemerintah Republik Indonesia No. 24 Tahun 2005 Tentang Standar Akuntansi Pemerintahan (SAP) Jakarta.

Pasuhuk, F. H., Kalangi, L., \& Warongan, J. D. L. (2018). Evaluasi sistem dan prosedur uang persediaan (up) pada dinas lingkungan hidup daerah Provinsi Sulawesi Utara. Going Concern: Jurnal Riset Akuntansi, 13(03), 294-302. https://ejournal.unsrat.ac.id/index.php/gc/article/view/20173

Renyowijoyo, M. (2008). Akuntansi sektor publik organisasi non laba. Jakarta: Mitra Wacana Media.

Sumarsan, T. (2013). Perpajakan Indonesia. Edisi 4. Jakarta: PT.Indeks

Soemarso, S.R. (1992). Akuntansi suatu pengantar. Yogyakarta: Salemba Empat

Undang - Undang Republik Indonesia Nomor 32 Tahun 2004 Tentang Pemerintahan Daerah 